\title{
Rain Water Balance of Finger Millet Cropping System in Alfisols of Bangalore Region, India
}

\author{
Laxman Jamadar $^{1 *}$, H. G. Ashoka ${ }^{2}$ and K. Devaraja ${ }^{3}$ \\ ${ }^{1}$ College of Agricultural Engineering, UAS, GKVK, Bengaluru-560065, India \\ ${ }^{2}$ Directorate of Research, UAS, GKVK, Bengaluru-560065, India \\ ${ }^{3}$ AICRP on Dryland Agriculture, UAS, GKVK, Bengaluru-560065, India \\ *Corresponding author
}

\begin{abstract}
A B S T R A C T
Keywords

Runn off, Soil

Moisture,

Evapotranspiration,

Deep percolation,

water balance

Article Info

Accepted:

28 March 2020

Available Online:

10 April 2020

The study on rain water balance of micro catchments under fingermillet cropping system of alfisols was carried out at the AICRPDA, GKVK, UAS Bangalore to work out the rain water balance in response to different soil and water conservation measures with varied slopes viz., $1.9 \%, 2.24 \%$ and $2.1 \%$. The total rainfall and ET crop during the finger millet cropping period was $604 \mathrm{~mm}$ and $250.98 \mathrm{~mm}$ respectively. The lowest and the highest runoff were observed in $\mathrm{T}_{1}$ and $\mathrm{T}_{4}$ respectively. Also the highest deep percolation was observed in $\mathrm{T}_{1}$. In general the study reveals a negative water balance for the finger millet crop during the year under study.

\section{Introduction}

Contour trench method of land development for soil and water conservation under dryland conditions was chosen in the semi-arid tropic of southern Karnataka. Contour trench fields were constructed manually for the finger millet cultivation. Contour trenches of any shape are the excavated depression across the land slope with the purpose of preventing soil erosion by trapping and absorbing sediments and runoff respectively. Contour trenches will help to collect runoff water and also breaks

the continuous slope of the ground and it results in reducing the velocity of runoff water. The reduced velocity of runoff is resulted in better opportunity time for infiltration reflected through reduced runoff and percolate down into the soil profile.

Runoff, soil and nutrients losses are sever in sloppy areas, which can be controlled by putting the continuous contour trenches. In recent years, such contour trench method of land development is recommended to the formers in the Karnataka state .The cross
\end{abstract}


section of the trenches can be of any size and shape like square, rectangle, trapezoidal or triangle. The choice of shape depends on the soil type and prevailing land slope. Square and rectangular shaped trenches are constructed in relatively flat land and minor undulating lands. Whereas in sloppy lands, trapezoidal or triangular trenches are constructed.

Very limited information is available about the rain water conservation in contour trenches under finger millet cropping system. In order to evaluate the contour trenches for rain water conservation in the sloppy areas, investigation was carried out during the year 2019-2020 at the All India Coordinated Research Project on Dry Land Agriculture, UAS, GKVK, Bengaluru with finger millet as a test crop.

The finger millet is the staple food crop in the southern part of the Karnataka state which is cultivated in more than 0.8 million hectares. The study of rain water balance will help in understanding the treatment effect in relation to water balance during the cropping period.

\section{Materials and Methods}

\section{Experimental site}

The present study was conducted at the All India Coordinated Research Project on Dry Land Agriculture, UAS, GKVK, Bengaluru. Geographically it is located at $12^{\circ} 58^{\prime}$ North latitude and $77^{\circ} 35^{\prime}$ East longitudes with an altitude of 924 meters above MSL. The experimental site comes under Eastern Dry Zone of Karnataka.

The experimental site predominantly consists of sandy loam soil. The annual rainfall of the region is $918.1 \mathrm{~mm}$ and more than 70 per cent of the rain received during the Kharif season (Manson).

\section{Treatment details}

Runoff from the three runoff plots viz; $\mathrm{T}_{1}, \mathrm{~T}_{2}$ and $\mathrm{T} 3$ was collected in the individual cisterns having the capacity/volume of $9.2 \mathrm{~m}^{2}$. As part of treatments, the $T_{1}$ and $T_{2}$ runoff plots are constructed with the trapezoidal shape trench having the cross sectional area of 0.09 $\mathrm{m}^{2}$ across the slope for a distance of $4 \mathrm{~m}$ plot width. The $T_{1}$ is constructed with the trench at $10 \mathrm{~m}$ interval.

There are two trenches constructed in this treatment having the total storage capacity of $73.6 \mathrm{~m}^{3}$. The $T_{2}$ is constructed with the trapezoidal shape trench at $25 \mathrm{~m}$ interval. The $\mathrm{T}_{2}$ is having single trench with the total runoff storage capacity of $36.8 \mathrm{~m}^{3}$. Hence the runoff in excess of the trench storage capacity can only be collected in the cistern. The $\mathrm{T}_{3}$ is not having any treatment measures and all the runoff is made to collect in the cistern. The three runoff plots for the treatment $T_{1}, T_{2}$ and $\mathrm{T}_{3}$ are having an area of $204 \mathrm{~m}^{2}$.

In addition $\mathrm{T}_{4}$ and $\mathrm{T}_{5}$ are also the two runoff plots having the individual plot with an area of $1184 \mathrm{~m}^{2} . \mathrm{T}_{4}$ andT $\mathrm{T}_{5}$ are constructed with multislot divisors for the collection of runoff. The multi slot divisors are having 15 slots and runoff from one slot is made to pass into the collection cistern.

Therefore the total runoff can be worked out by multiplying with 15 for the quantity of runoff collected in the respective plot cisterns. Further the treatment details is as fallows,

1. $\mathrm{T}_{1}$-Trenches at $10 \mathrm{~m}$ interval at slope $1.7 \%$

2. $\mathrm{T}_{2}-$ Trenches at $25 \mathrm{~m}$ interval at slope $1.93 \%$

3. $\mathrm{T}_{3}$ - Field conditions at slope $1.9 \%$

4. $\mathrm{T}_{4}$ - Field condition at slope $2.24 \%$

5. $\mathrm{T}_{5}$ - Field condition at slope $2.1 \%$ 


\section{Hydrological data}

To estimate the water balance of the runoff plots, the data on rainfall, runoff, soil moisture, deep percolation and evapotranspiration losses were worked out by following the Mc Gowan and Williams (1980) equation. Rainfall was recorded by an automatic siphon type rain gauge, which is installed at the weather station located adjacent to the experimental plots. Also the data on atmospheric relative humidity, wind speed and pan evaporation (A standard United States Weather Bureau Class A pan) were recorded from the observatory. Penman method was adopted for estimating the reference crop evapotranspiration (Allen et al., 1998.). The details of penman method of estimation of actual evapotranspiration is detailed further as;

$E t_{o}=\frac{0.408 \Delta\left(\mathrm{R}_{\mathrm{n}}-\mathrm{G}\right)+\mathrm{y}\left(\frac{900}{\mathrm{~T}+273}\right) \mathrm{u}_{2}\left(\mathrm{e}_{\mathrm{s}}-\mathrm{e}_{\mathrm{a}}\right)}{\Delta+\mathrm{y}\left(1+0.34 \mathrm{u}_{2}\right)}$

Where,

$\mathrm{Rn}$ is the net radiation

$\mathrm{G}$ the soil heat flux density

$\mathrm{T}$ the air temperature

$\mathrm{u}_{2}$ wind speed

$\mathrm{e}_{\mathrm{s}}$ vapour pressure of the air at saturation

$\mathrm{e}_{\mathrm{a}}$ actual vapour pressure

$\mathrm{y}$ is the psychrometric constant

Bi Weekly per cent soil moisture was worked out gravimetrically on oven dry basis for the soil depth of $15 \mathrm{~cm}, 30 \mathrm{~cm}$ and $45 \mathrm{~cm}$. The percent soil moisture was converted to depth of water in $\mathrm{mm}$ by following the procedure adopted by Sing et al., (1960). Since the water balance study was carried out on monthly basis, soil moisture in the beginning and at the end of the month was considered to estimate the soil moisture held in the soil. Soil moisture was monitored up to the depth of 45 $\mathrm{cm}$ since the test crop is finger millet being shallow rooted.

\section{Rain water balance}

The hydrologic water balance equation used for this study was the one used by Mc Gowan and Williams (1980). The equation is explained further,

$\mathrm{P}=\mathrm{R}+\mathrm{E}+\delta \mathrm{S}+\mathrm{U}$

Where,

$\mathrm{P}=$ precipitation over the catchment

$\mathrm{R}=$ Runoff from the catchment

$\mathrm{E}=$ Evapotranspiration losses

$\delta \mathrm{S}=$ Change in soil moisture storage

$\mathrm{U}=$ Deep percolation

All the parameters are expressed in $\mathrm{mm}$.

\section{Results and Discussion}

\section{Rainfall}

Intensity and duration of rainfall is one of the major inputs to produce runoff. The normal rainfall of the region is $918.1 \mathrm{~mm}$. During the year, the total rainfall received was 918.1. Monthly rainfall of 173.4, 186.6, 234 and 10 $\mathrm{mm}$ recorded for the month of August, September, October and November respectively. In general there are 8, 6 and 5 runoff causing rainfall events recorded for the month of October, September and August respectively

\section{Reference crop evapotranspiration (ET crop)}

The reference crop evapotranspiration for finger millet crop is common for all the treatments and it is accounted as $250.92 \mathrm{~mm}$ (Table 2). ET crop worked out to be showing increase trend up to crop grand growth period and declines as it approaches maturity period. ET crop was maximum during the eared development stage (66 to $88^{\text {th }}$ days after sowing). 


\section{Runoff}

Intensity and duration of rainfall is one of the major inputs to induce runoff. During the experimental period, the treatment $\mathrm{T}_{1}$ resulted in lowest runoff $(151.09 \mathrm{~mm})$ from among the treatment. This may be due to the treatment effect of closer trenches at $10 \mathrm{~m}$ interval which is resulted in breaking of the continuous slopes reducing the runoff and conserving the rain water in the field itself. The $\mathrm{T}_{1}$ is having the trench with the total capacity of $73.6 \mathrm{~m}^{3}$.

In contrast the highest runoff was observed in $\mathrm{T}_{4}(230.42 \mathrm{~mm})$ having the highest field slope of $2.40 \%$. The reason for higher amount of runoff may be attributed to the higher slopes. Similar trend was also observed in other treatments. The treatment $\mathrm{T}_{2}$ is having the trenches at $25 \mathrm{~m}$ interval with the total trench volume of $36.8 \mathrm{~m}^{3}$ and the treatment $\mathrm{T}_{3}$ has no treatment measures.

Though the $\mathrm{T}_{2}$ is having higher land slope of $1.93 \%$ than $\mathrm{T}_{3}$ with $1.90 \%$, the runoff collected was lower. This is mainly due to the treatment effect of trench provided at $25 \mathrm{~m}$ interval having the trench capacity $36.80 \mathrm{~m}^{3}$. Therefore the reduced trend of the runoff was in the order of $\mathrm{T}_{1}<\mathrm{T}_{2}<\mathrm{T}_{3}<\mathrm{T}_{5}<\mathrm{T}_{4}$. The Findings are in conformity with the observation of Asokha et al., (1995.) They reported that the higher slopes results in an increased runoff. The results are presented in the table 1 .

\section{Micro catchment water balance}

Monthly water balance accounted in the different treatments reveals that there was direct correlation between runoff and slope. The higher runoff was observed with an increased slope (Table 3). The runoff was maximum in the treatment $\mathrm{T}_{4}$ having 2.24 percent slope and it was minimum in the
$\mathrm{T}_{1}$ with 1.7 percent slopes. The results are in conformity with the findings of Asokha et al., (1995) and Rama Sastri (1975).

Further the higher deep percolation generally observed in all the treatments during the October 2019. Generally the observation of runoff and deep percolation exhibited the inverse relationship. The treatments observed the higher amount of runoff resulted in lower amount of deep percolation. The highest deep percolation of $107.75 \mathrm{~mm}$ was observed during October 2019 for the $\mathrm{T}_{1}$ which is having slope of $1.7 \%$ slope. The lowest deep percolation of $2.95 \mathrm{~mm}$ was observed during September 2019 for $\mathrm{T}_{4}$ having the highest slope of $2.24 \%$.

Seasonal water balance during the finger millet cropping period for the treatments $T_{1}$, $\mathrm{T}_{2}, \mathrm{~T}_{3}, \mathrm{~T}_{4}$ and $\mathrm{T}_{5}$ were worked out for the total rainfall of $604 \mathrm{~mm}$ (Table 4). The total seasonal water balance for different component accounted as $662.59 \mathrm{~mm}$ in $\mathrm{T}_{1}(\mathrm{R}$, $\mathrm{E}, \delta \mathrm{S}$ and $\mathrm{U}$ ) against the seasonal rainfall of $604 \mathrm{~mm}$. This implies a negative water balance of $58.45 \mathrm{~mm}$.

There is a need for better rain water management from the point of crop growth and productivity. The treatment $T_{1}$ with trenches at $10 \mathrm{~m}$ interval targeted to harvest the rainwater of $73.6 \mathrm{~m}^{3}$. Also the $\mathrm{T}_{2}$ has got the trenching at $25 \mathrm{~m}$ interval with 36.8 $\mathrm{m}^{3}$ water harvesting capacity.

Therefore the total water balance among the five different treatments during the cropping period better reflected for $T_{1}$ followed by $T_{2}$. The treatments $T_{3}, T_{4}$ and $T_{5}$ do not have the conservation measures reflected in lower deep percolation. Also the treatments $\mathrm{T}_{3}, \mathrm{~T}_{5}$ and $\mathrm{T}_{4}$ are having higher slopes from each other and the seasonal rain water balance reflected accordingly. 
Table.1 Rainfall and runoff under different treatments for finger millet cropping system at the GKVK campus during 2019

\begin{tabular}{|c|c|c|c|c|c|c|}
\hline Date & $\begin{array}{c}\text { Rainfall } \\
\text { (mm) }\end{array}$ & $\mathbf{T}_{1}$ & $\mathbf{T}_{2}$ & $\mathbf{T}_{3}$ & $\mathbf{T}_{4}$ & $\mathbf{T}_{5}$ \\
\hline 15-08-2019 & 24.6 & 9.92 & 10.82 & 11.72 & 13.30 & 12.32 \\
\hline 18-08-2019 & 14.2 & 1.80 & 2.25 & 4.50 & 6.96 & 5.3571 \\
\hline 19-08-2019 & 23.4 & 4.50 & 4.96 & 6.31 & 10.07 & 10.71 \\
\hline 20-08-2019 & 35.4 & 12.17 & 12.62 & 14.43 & 15.58 & 14.12 \\
\hline 21-08-2019 & 14.8 & 4.50 & 2.70 & 4.50 & 5.85 & 5.15 \\
\hline 30-08-2019 & 24 & 10.82 & 12.62 & 10.82 & 12.56 & 11.02 \\
\hline 19-09-2019 & 71.2 & 43.29 & 43.74 & 44.64 & 47.05 & 46.86 \\
\hline 23-09-2019 & 28.4 & 8.11 & 5.41 & 12.17 & 15.09 & 14.81 \\
\hline 24-09-2019 & 26.4 & 1.8 & 3.60 & 4.50 & 5.88 & 5.32 \\
\hline 25-09-2019 & 20.4 & 4.5 & 4.96 & 6.31 & 9.86 & 8.736 \\
\hline 26-09-2019 & 7.6 & 0 & 0 & 2.70 & 3.8 & 3.34 \\
\hline 02-10-2019 & 26.2 & 2.25 & 2.70 & 3.60 & 6.08 & 5.82 \\
\hline 03-10-2019 & 12.4 & 1.35 & 1.35 & 2.25 & 3.12 & 2.97 \\
\hline 04-10-2019 & 17.2 & 2.7 & 2.70 & 4.50 & 6.66 & 5.85 \\
\hline 05-10-2019 & 16.6 & 1.8 & 3.15 & 4.50 & 5.79 & 5.07 \\
\hline 09-10-2019 & 35.2 & 12.17 & 12.62 & 14.43 & 16.03 & 15.35 \\
\hline $10-10-2019$ & 28.8 & 18.03 & 18.94 & 24.35 & 26.15 & 25.84 \\
\hline 22-10-2019 & 33.4 & 5.41 & 5.86 & 8.11 & 10.78 & 10.12 \\
\hline 28-10-2019 & 33.2 & 5.86 & 4.96 & 7.21 & 9.81 & 9.07 \\
\hline Total & 493.4 & 150.98 & 156.03 & 191.66 & 230.432 & 217.83 \\
\hline
\end{tabular}


Table.2 Estimated actual evapotranspiration for the finger millet crop during 2019

\begin{tabular}{|c|c|c|c|}
\hline Period & ET Crop $\quad(\mathrm{mm})$ & No. of days & crop duration (days) \\
\hline 01-08-19 to 11-08-19 & 11.98 & 11 & 11 \\
\hline 12-08-19 to 22-08-19 & 12.99 & 11 & 22 \\
\hline 23-08-19 to 02-09-19 & 15.38 & 11 & 33 \\
\hline 03-09-19 to $13-09-19$ & 19.97 & 11 & 44 \\
\hline 14-09-19 to 24-09-19 & 27.78 & 11 & 55 \\
\hline $25-09-19$ to $05-10-19$ & 32.07 & 11 & 66 \\
\hline $06-10-19$ to $16-10-19$ & 33.18 & 11 & 77 \\
\hline $17-10-19$ to $27-10-19$ & 31.24 & 11 & 88 \\
\hline $28-10-19$ to 07-11-19 & 27.25 & 11 & 99 \\
\hline 08-11-19 to 18-11-19 & 20.09 & 11 & 110 \\
\hline 08-11-19 to 18-11-19 & 20.09 & 11 & 110 \\
\hline 19-11-19 to 29-11-19 & 16.07 & 11 & 122 \\
\hline $30-11-19$ to $31-11-19$ & 2.92 & 2 & 124 \\
\hline Total & 250.92 & 124 & 124 \\
\hline
\end{tabular}

Table.3 Monthly Rain water balance under finger millet crop at the GKVK campus during 2019

\begin{tabular}{|c|c|c|c|c|c|c|}
\hline Treatments & $\begin{array}{c}\text { Months } \\
\text { mm }\end{array}$ & $\begin{array}{c}\text { Rainfall } \\
\mathbf{m m}\end{array}$ & $\begin{array}{l}\text { Runoff } \\
\text { Mm }\end{array}$ & $\begin{array}{c}\text { Evapo- } \\
\text { traspiration } \\
\text { (ET) } \mathrm{Mm}\end{array}$ & $\begin{array}{l}\text { Change in soil } \\
\text { moisture } \\
\text { storage }(\delta S) \mathrm{Mm}\end{array}$ & $\begin{array}{c}\text { Deep } \\
\text { percolation } \\
\text { (U) } \mathbf{~ m m}\end{array}$ \\
\hline \multirow{4}{*}{$\mathbf{T}_{1}$} & August & 173.4 & 43.75 & 37.36 & 49.12 & 43.17 \\
\hline & September & 186.6 & 57.73 & 68.39 & 43.81 & 16.68 \\
\hline & October & 234 & 49.61 & 89.62 & -12.98 & 107.75 \\
\hline & November & 10 & 0.00 & 55.62 & 8.21 & - \\
\hline \multirow[t]{4}{*}{$\mathbf{T}_{2}$} & August & 173.4 & 46 & 37.36 & 46.46 & 43.57 \\
\hline & September & 186.6 & 57.72 & 68.38 & 41.15 & 19.33 \\
\hline & October & 234 & 52.31 & 89.61 & -15.66 & 107.73 \\
\hline & November & 10 & 0 & 55.61 & 6.90 & - \\
\hline \multirow[t]{4}{*}{$\mathbf{T}_{\mathbf{3}}$} & August & 173.4 & 52.31 & 37.36 & 35.90 & 47.81 \\
\hline & September & 186.6 & 70.35 & 68.38 & 40.04 & 7.811 \\
\hline & October & 234 & 69 & 89.61 & -19.02 & 94.41 \\
\hline & November & 10 & 0 & 55.61 & 7.01 & - \\
\hline \multirow[t]{4}{*}{$\mathbf{T}_{4}$} & August & 173.4 & 64.32 & 37.36 & 31.37 & 40.34 \\
\hline & September & 186.6 & 81.68 & 68.38 & 33.56 & 2.95 \\
\hline & October & 234 & 84.42 & 89.61 & -21.24 & 81.20 \\
\hline & November & 10 & 0 & 55.61 & 5.51 & - \\
\hline \multirow[t]{4}{*}{$\mathbf{T}_{5}$} & August & 173.4 & 58.68 & 37.36 & 33.12 & 44.23 \\
\hline & September & 186.6 & 79.06 & 68.38 & 35.84 & 3.30 \\
\hline & October & 234 & 80.89 & 89.61 & -20.24 & 83.73 \\
\hline & November & 10 & 0 & 55.61 & 6.85 & - \\
\hline
\end{tabular}


Table.4 Seasonal rain water balance under finger millet crop at GKVK campus during 2019

\begin{tabular}{|c|c|c|c|c|c|}
\hline Treatments & $\begin{array}{c}\text { Total } \\
\text { seasonal } \\
\text { Rainfall } \\
(\mathbf{m m})\end{array}$ & $\begin{array}{c}\text { Runoff } \\
(\mathbf{m m})\end{array}$ & $\begin{array}{c}\text { Evapotranspiration } \\
\mathbf{( E T )}\end{array}$ & $\begin{array}{c}\text { Change in soil } \\
\text { moisture } \\
\text { storage } \mathbf{( S )}\end{array}$ & $\begin{array}{c}\text { Deep } \\
\text { percolation } \\
(\mathbf{m m})\end{array}$ \\
\hline $\mathbf{T}_{\mathbf{1}}$ & 604 & 151.07 & 250.98 & 92.95 & 170.64 \\
\hline $\mathbf{T}_{\mathbf{2}}$ & & 156.03 & 250.98 & 87.61 & 167.6 \\
\hline $\mathbf{T}_{\mathbf{3}}$ & & 191.66 & 250.98 & 75.95 & 150.03 \\
\hline $\mathbf{T}_{\mathbf{4}}$ & & 230.43 & 250.98 & 64.93 & 124.5 \\
\hline $\mathbf{T}_{\mathbf{5}}$ & & 218.63 & 250.98 & 68.96 & 131.27 \\
\hline
\end{tabular}

The highest runoff with lowest deep percolation was observed in $\mathrm{T}_{4}$ and the lowest runoff of $T_{1}$ is attributed to be treatments with trenches at $10 \mathrm{~m}$ intervals. The highest runoff observed in $\mathrm{T}_{4}$ is attributed to the runoff plots having no conservation measures.

The intensity and duration of rainfall had much influence on the runoff. The trenches at $10 \mathrm{~m}$ closer interval helped to retain the moisture in the field reducing the runoff, whereas with the same amount of rainfall, higher runoff was observed for the $\mathrm{T}_{4}$ plot having the slope of 2.4 percent. On the contrary lower amount of rainfall with very low intensity had not produced runoff in lower slopes plots.

Also the control measures play an important role in reducing runoff and helps in deep percolation. Accordingly, treatment $\mathrm{T}_{1}$ is having trenches at $10 \mathrm{~m}$ interval resulted in more conservation of rain water which helps in increased deep percolation. The treatments $\mathrm{T}_{3}, \mathrm{~T}_{4}$ and $\mathrm{T}_{5}$ did not have any conservation measures and resulted in higher runoff.

Monthly water balance of treatments with different slope indicated that there was lower runoff reflected through highest deep percolation observed in $\mathrm{T}_{1}$ with $1.7 \%$ slope.
The treatments $\mathrm{T}_{1}, \mathrm{~T}_{2}$ and $\mathrm{T}_{3}$ having the landslope of $1.7,1.93$ and $1.90 \%$ respectively yielded the lower quantity of runoff compare to $\mathrm{T}_{4}$ and $\mathrm{T}_{5}$.

\section{References}

ALLEN, R.G., PEREIRA, L.S., RAES, D. AND SMITH, M., 1998, Crop evapotranspiration-Guidelines for computing crop water requirementsFAO Irrigation and drainage paper 56. Fao, Rome., 300(9): 109.

ASHOKA, H.G., CHANNAPPA, T.C., AND RAMAIAH, R., 1995, Water Balance Studies of Graded Border strips in Alfisols. Indian J. Dryland agric. Res and Dev., 10 (2):131-138.

MCGOWAN, M., AND WILLIAMS, J.B., 1980, The water balance of an agricultural catchment. Estimation of evaporation from soil water records. Journal of soil Science., 31(2): 217-230.

MCGOWAN, M., WILLIAMS, J.B., AND MONTEITH, J.L., 1980, The Water Balance of an Agricultural Catchment of the Water Balance. Journal of Soil Science., 31(2): 245-262.

REYNOLDS, S.G., 1970, The gravimetric method of soil moisture determination 
Part IA study of equipment, and methodological problems. Journal of Hydrology., 11 (3): 258-273.

RAMA SASTRI, K.S., 1975, Estimation of runoff by water balance technique. Proceedings of National Symposium on
Hydrology, Roorkee, U.P. SINGH, P., and RUSSELL, M.B., 1979. Water Balance and Profile Moisture Loss Patterns of an Alfisol 1. Agronomy Journal., 71(6):963-966.

\section{How to cite this article:}

Laxman Jamadar, H. G. Ashoka and Devaraja, K. 2020. Rain Water Balance of Finger Millet Cropping System in Alfisols of Bangalore Region, India. Int.J.Curr.Microbiol.App.Sci. 9(04): 3110-3117. doi: https://doi.org/10.20546/ijcmas.2020.904.363 